\title{
Ulusal Enerji Tüketiminin Değerlendirmesi ve İstatistiksel Tahmini
}

\author{
Can B. AKTAŞ* \\ TED Üniversitesi, Inşaat Mühendisliği Bölümü, Ankara \\ (ORCID: 0000-0001-8356-1812)
}

\section{$\ddot{O} \mathbf{z}$}

Türkiye, dünyada enerji tüketimi en hızlı artan ülkeler arasında yer almaktadır ve artışın yakın gelecekte değişmesi beklenmemektedir. Ulusal düzeyde yenilenebilir enerjinin payının artırılması, enerji ithalatında ülke ve güzergâh çeşitliliğ̈inin artırılması ve genel enerji verimliliğinin artırılmasına yönelik çalışmalarda bulunulması ülkenin resmi enerji hedef ve politikaları arasında yer almaktadır. Araştırmanın amacı Türkiye'deki enerji tüketiminin istatistiksel tahmini, binaların genel toplamdaki payı ve mevcut tüketim seviyesinin korunması veya azaltılması için yapılarda enerji verimliliği hedeflerinin tespit edilmesini kapsamaktadır. Çalışma yürürlükte olan devlet politikalarını bilimsel olarak desteklemekte ve sonuçlarıyla katkıda bulunmaktadır. Çalışma aynı zamanda sonuçları itibariyle Türkiye'nin enerji altyapısındaki sistematik esnekliği artırmaya ve mevcut enerji bağımlılık ve güvenlik açıklıklarının belirlenmesi ve nihai olarak azaltılmasını hedeflemektedir. Enerji tüketim seviyesinin istatistiksel değerlendirmesi sonucu elde edilen güven aralığı ulusal enerji politikalarına ve önceliklerine yön verme potansiyeli açısından da son derece önemlidir. 2030 yllında beklenen toplam enerji tüketiminin ortalama değeri 152 milyon TPE seviyesindedir ve $\% 95$ olasılıkla tüketimin 122-182 milyon TPE değerleri arasında olması beklenmektedir ki bu değer toplam enerji tüketiminin 14 yıl içinde yaklaşık \%40 arttığını göstermektedir. Yapılardaki enerji tüketimini incelediğimizde ise öngörülen ortalama değerin 48 milyon TPE seviyesinde, ve \%95 güven aralı̆̆ının 37-59 milyon TPE seviyelerinde olduğu tespit edilmiştir. Bu değerler, 2017 yılı tüketimi olan 36 milyon TPE seviyesinden ortalama beklenti olarak \%33 artacağını, en iyi ihtimalle yatay seyredeceğini ve hızlı artış durumunda ise \%64 kadar artacağını göstermektedir. Enerji tüketimini etkileyen etkenler incelendiğinde, GSYH endeksinin enerji tüketimine etkisinin en fazla olduğu tespit edilmiştir. Enerji ithalatının toplama oranı tutarlı olarak artmış ve \%40 seviyesinden 2017 yllında \%85 seviyesine ulaşmıştır. Mevcut veriler ve değerlendirmeler Türkiye'nin toplam enerji seviyesini 2017 yılı seviyesinde korumasının sadece yapıların enerji verimliliği ile mümkün olmadığını göstermektedir. Buna ek olarak, toplam enerji tüketiminin kısa vadede sabitlenmesi veya azalması olası gözükmemektedir. Artan nüfus ve kişi başına düşen enerji tüketimi değerleri de bu sonucu desteklemektedir. Yapılması gereken çevresel, sosyal ve ekonomik hedef ve önceliklerin belirlenmesi ve enerji tüketiminin artacağı varsayımıyla bu hedeflere doğru etkin politikalar geliştirilmesi ve uygulanmasıdır.

Anahtar kelimeler: Enerji tüketimi, yapılarda enerji verimliliği, enerji tahmini, enerji politikaları.

\section{National Energy Consumption Assessment and Statistical Forecast}

\begin{abstract}
Turkey is among the fastest growing countries in the world in terms of energy consumption, and the trend is not expected to change in the near future. Increasing the share of renewable energy at the national level, increasing the diversity of countries and routes in energy importation, and increasing the overall energy efficiency are among the official energy targets and policies of the country. The goal of this study is to statistically forecast energy consumption in Turkey, assess the share of building energy use within the total, and determine building energy efficiency targets in order to preserve. Or reduce current energy consumption levels. The study and its results provide scientific support towards state policies in effect. The study also aims to improve resilience of the energy infrastructure, and determine current energy dependence and vulnerabilities in order to mitigate their effects. The confidence interval obtained as a result of the statistical evaluation of the energy consumption level is also important in terms of the potential to direct national energy policies and priorities. The average expected value of total energy consumption in year 2030 is 152 million TPE, and the $95 \%$ confidence interval indicates that total
\end{abstract}

"Sorumlu yazar: can.aktas@tedu.edu.tr

Geliş Tarihi: 21.03.2019, Kabul Tarihi: 11.07.2019 
energy consumption is expected to be between 122-182 million TPE. These numbers indicate that total energy consumption is expected to increase by $40 \%$ within the next 14 years. When we examine energy consumption in buildings, it is determined that the projected expected value is 48 million TPE, with a 95\% confidence interval of 37-59 million TPE. These values indicate that the energy consumption of 36 million TPE in 2017 is expected to increase by $33 \%$ on average, will be flat in the best-case scenario, and increase by $64 \%$ in case of a rapid increase. When factors affecting energy consumption are examined, it is determined that the effect of GDP on energy consumption is the most dominant factor. The ratio of energy imports to total consumption has steadily and consistently increased and reached 85\% in 2017 from 40\% in early 1970's. Existing data and the assessment carried out indicate that is not possible to maintain Turkey's total energy consumption levels in 2017 through only focusing on building energy efficiency. In addition, it is unlikely that total energy consumption will peak or start a decline in the short term. Increasing population and per capita energy consumption values support this conclusion. It is necessary to develop environmental, social and economic targets and implement effective policies towards these targets with the expectation that energy consumption will increase.

Keywords: Energy consumption, Building energy efficiency, Energy forecast, Energy policies.

\section{Giriş}

Geçtiğimiz on senelik sürede Türkiye OECD ülkeleri arasında enerji tüketimi en hızla yükselen ülke olmasının yanı sıra, bu süre zarfında dünya çapında da Çin' in ardından en fazla talep artış hızına sahip ikinci ülke olmuştur. Mevcut beklentiler bu gidişatın kısa ve orta vadede devam edeceği yönündedir. Bunun yanı sıra, günümüzde tüketilen toplam enerjinin büyük bir kısmı ithal edilmektedir. Örneğin, yakıt türlerinden konutlar için önem teşkil eden doğalgazda tüketilen yakıtın \%99'u ithal edilmektedir. $\mathrm{Bu}$ durumun ülke ekonomisine ve dış ilişkilere olan etkilerinin yanı sıra, yakıt ithalatında meydana gelebilecek ufak aksaklıkların sosyal ve ekonomik etkilerinin ciddi boyutlara ulaşması beklenebilir [12].

Türkiye nüfusu 1990 yılında 57 milyondan, 2008 yılında 72 milyona ulaşmıştır. Nüfus artışına ek olarak, Türkiye'nin şehirleşme oranı $\% 53$ 'den $\% 75$ 'e ulaşmıştır aynı süre zarfında. Bu nüfus hareketlerinin sonucu olarak konut sayısı ve dolayısıyla konutlarda enerji tüketimi hızla artmıştır [1]. Elektrik tüketimi, gelişen ekonomi ve artan kentleşme oranı sonucu 1990-2008 yılları arası üç kat artmış ve 198 TWh seviyesine ulaşmıştır.

2008 yılında tüketilen toplam enerjinin \%36'sı binalarda kullanılmıştır. Kullanılan enerjinin \%70'i ısıtma ve sıcak su için kullanılmıştır [1]. Enerji masrafı ortalama hanehalkı bütçesinin \%25'ini teşkil etmektedir ve mevcut yöntemler ve genel akımlar devam ettiği sürece bu oranın artması beklenmektedir.

$\mathrm{Bu}$ veriler doğrultusunda, enerji konusunun kısa ve orta vadede Türkiye'nin gündemindeki önemli konular arasında olması beklenebilir. Buna bağlı olarak, enerji tüketiminin azaltılması ve enerji verimliliğinin hızla artırılmasının önemi açıktır. Ulusal düzeyde yenilenebilir enerjinin payının artırılması, enerji ithalatında ülke ve güzergâh çeşitliliğinin artırılması ve genel enerji verimliliğinin artırılmasına yönelik çalışmalarda bulunulması ülkenin resmi enerji hedef ve politikaları arasında yer almaktadır. Mevcut çalışma, bu hedef doğrultusunda yakın vadede Türkiye'deki enerji tüketiminin istatistiksel tahmini, binaların genel toplamdaki payı ve mevcut tüketim seviyesinin korunması veya azaltılması için yapılarda enerji verimliliği hedeflerinin tespit edilmesini kapsamaktadır. Dolayısıyla önerilen çalışma yürürlükte olan devlet politikalarını bilimsel olarak desteklemekte ve sonuçlarıyla katkıda bulunmaktadır. Çalışma aynı zamanda sonuçları itibariyle Türkiye'nin enerji altyapısındaki sistematik esnekliği artırmaya ve mevcut enerji bağımlılık ve güvenlik açıklıklarını azaltmayı hedeflemektedir. Enerji tüketim seviyesinin istatistiksel değerlendirmesi sonucu elde edilecek güven aralığı ulusal enerji politikalarına ve önceliklerine yön verme açısından da son derece önemlidir.

\section{Yöntem}

Bu kısım çalışma esnasında kullanılan istatistiksel yöntemlerin bilimsel temelini, uygulamasını ve bazı noktalarda gerekli olarak kullanılan varsayımları açıklamaktadır. 


\title{
2.1. İstatistiksel değerlendirme ve kullanılan yöntemler
}

\begin{abstract}
Ĕgilim çizgisi
Eğilim çizgisi yöntemi verilerin yorumlanmasında kullanılan istatistiksel bir yöntemdir. Belirlenen eğilim çizgisi hem veriyi betimlemek için hem de geleceğe yönelik basit değerlendirmeler yürütmek için kullanılabilir. En küçük kareler yöntemi uygulamasıyla, mevcut veriyle olası çizgi arasındaki hatanın karelerinin toplamı olarak hesaplanan ve sonucunda en az hatayı sunan eğilim çizgisi seçilir. Buradaki amaç hatayı, yani eğilim çizgisi ile veri noktaları arsındaki farkı en aza indirgemektir. Mevcut çalışmada zaman serisi verilerinin değerlendirildiği noktalarda, çalışmanın amacına yönelik olarak önemli kabul edilen etmenlerde eğilim çizgisi belirlenmiş ve ilgili şekilde belirtilmiştir.
\end{abstract}

\section{R-kare testi}

Regresyon değerlendirmesinde kullanılan eğilim çizgisinin mevcut veriye uygunluğunu belirlemek için sıkça kullanılan istatistiklerden biri de $\mathrm{R}^{2}$ değeridir. Hesaplanan bu değer 0 ve 1 arasında olmak zorundadır ve daha yüksek değerler genel olarak verideki varyasyonun azlığını ve eğilim çizgisinin mevcut veriyle uygunluğunu belirtir. Her alan için beklenen $\mathrm{R}^{2}$ değerleri farkl11ık gösterir, bu nedenle genel geçer kabul edilebilir en az veya en çok değerleri tespit edilememiştir. Mevcut çalışmada eğilim çizgilerinin tespitinin ardından R2 istatistiği hesaplanmış ve ilgili şekillerde sunulmuştur. Hesaplanan değerler 1'e yakındır ve dolayısıyla kullanılan eğilim çizgisinin geçerliğini göstermektedir.

\section{Arima modeli ile Monte Carlo simülasyonu}

Monte Carlo simülasyonu istatistiksel değerlendirmelerde ve özellikle olasılık hesabının değerlendirmeye katılması istenen durumlarda sıkça kullanılan bir yöntemdir. İstatistiksel dağılımı tanımlanmış farklı etmenlerden rasgele örneklem seçimi vasıtasıyla sayısal sonuçların elde edilmesini olanaklı kılar. Eldeki soruya bağlı olarak değerlendirmenin tekrarlama sayısı belirlenerek hızlı bir şekilde istatistiksel değerlendirme gerçekleştirilebilir. Mevcut çalışmada tekrarlama seviye 1.000 olarak seçilmiştir. Monte Carlo yönteminin en önemli özelliklerinden biri ise sonuçların sadece ortalama değerinden ziyade güven aralığının da belirlenmesini sağlar. Bilimsel ve mühendislik çalışmalarında sıkça ihtiyaç duyulan ve kullanılan bir özelliktir. Mevcut çalışmada da sonuçlar \%95 güven aralı̆ğ ve iki kuyruklu test kullanılarak hesaplanmış ve sunulmuştur.

Zaman serisi analizlerinde geleceğe yönelik tahminlerin yürütüldüğü çalışmalarsa sıklıkla kullanılan Autoregressive Integrated Moving Average (ARIMA) modeli mevcut çalışmada da uygulanmıştır. Model geçmiş verileri kullanarak bunlar üzerinde regresyon analizi uygulamaya ve geleceğe yönelik tahminler yapılmasını sağlar. Diğer regresyon modellerinde olduğu gibi mevcut veriye uygunluk ve uyumluluk esastır. Bu model Monte Carlo yöntemiyle eşlendiğinde tekrarlama sayısı kadar farklı sonuç verecektir ve bunların genelinin değerlendirmesi sonucunda ortalama değer ve güven aralıkları belirlenmektedir.

\subsection{Konutlarla ilgili varsayımlar}

Konutlarla ilgili elde edilen verilerle ilgili belirtilmesi gereken bir nokta vardır. Türkiye'de toplam ve sektörel enerji tüketimi incelendiğinde, en kapsamlı veriyi sunan Enerji İşleri Genel Müdürlüğü istatistiklerinde 2015 yılına kadar konut ve hizmetler başlığı altında sunulan kategori, 2015'ten itibaren 'Konut' ve 'Ticaret ve Hizmetler' başlıkları altında ikiye ayrılmıştır. Şekil 1'de 2015'ten itibaren sunulan değerler önceki verilerle tutarlı olması açısından bu iki kategorinin toplanması ve beraber sunulmasıyla elde edilmiştir. Yapılar arasında Konut ve Ticaret ve Hizmetler kategorilerinin oranı incelenmiştir. 2015 yılı için konutlar mesken ve ticari yapılar toplamının \%59'unu, 2016 yılı için toplamın \%61'ini ve güncel olarak yayınlanan 2017 yılı için ise \%64'ünü oluşturmuşlardır. Konutlarla ilgili sonuç ve öneriler sunulurken bu nokta değerlendirmeye alınmıştır.

\section{Tahmini enerji tüketim seviyesinin belirlenmesi}

Türkiye'nin 1972-2017 yılları arası toplam ve sektörel enerji tüketimi, Enerji İşleri Genel Müdürlügü tarafindan sunulan veriler değerlendirilerek yıllar içindeki değişim tespit edilmiştir. Buna göre, toplam enerji tüketimi bu süre zarfında 20 milyon ton petrol eşdeğeri (TPE) seviyesinden 111 milyon TPE seviyesine çıkmış, yani 46 yıl içerisinde toplam enerji tüketiminde 5,5 kat artış gerçekleşmiştir. Şekil 1 1972-2017 yılları arası toplam ve sektörel enerji tüketimindeki eğilimleri göstermektedir. Çalışmanın 
amacına yönelik olarak ve geçmiş verilere ek olarak, ileriye yönelik tüketim tahmin değerlendirmesi gerçekleştirilmiş ve ilgili eğilimler aynı şekil üzerinde belirtilmiştir. Toplam enerji tüketimini eğilim çizgisi ile betimlemeye çalıştığımızda doğrusal veya üstel fonksiyonlar kullanmak mümkündür. Fakat şekil üzerinde belirtilen $\mathrm{R}^{2}$ uygunluk istatistiğine bakarak üstel dağılımın daha uygun olduğu gözlemlenebilir. Konut ve ticari yapıların enerji tüketimi incelendiğinde her iki tip fonksiyon arasında görsel olarak çok fazla fark olmamakla birlikte üstel eğilim çizgisinin $\mathrm{R}^{2}=0,958$ uygunluk istatistiğiyle daha uygun olduğu tespit edilmiştir.

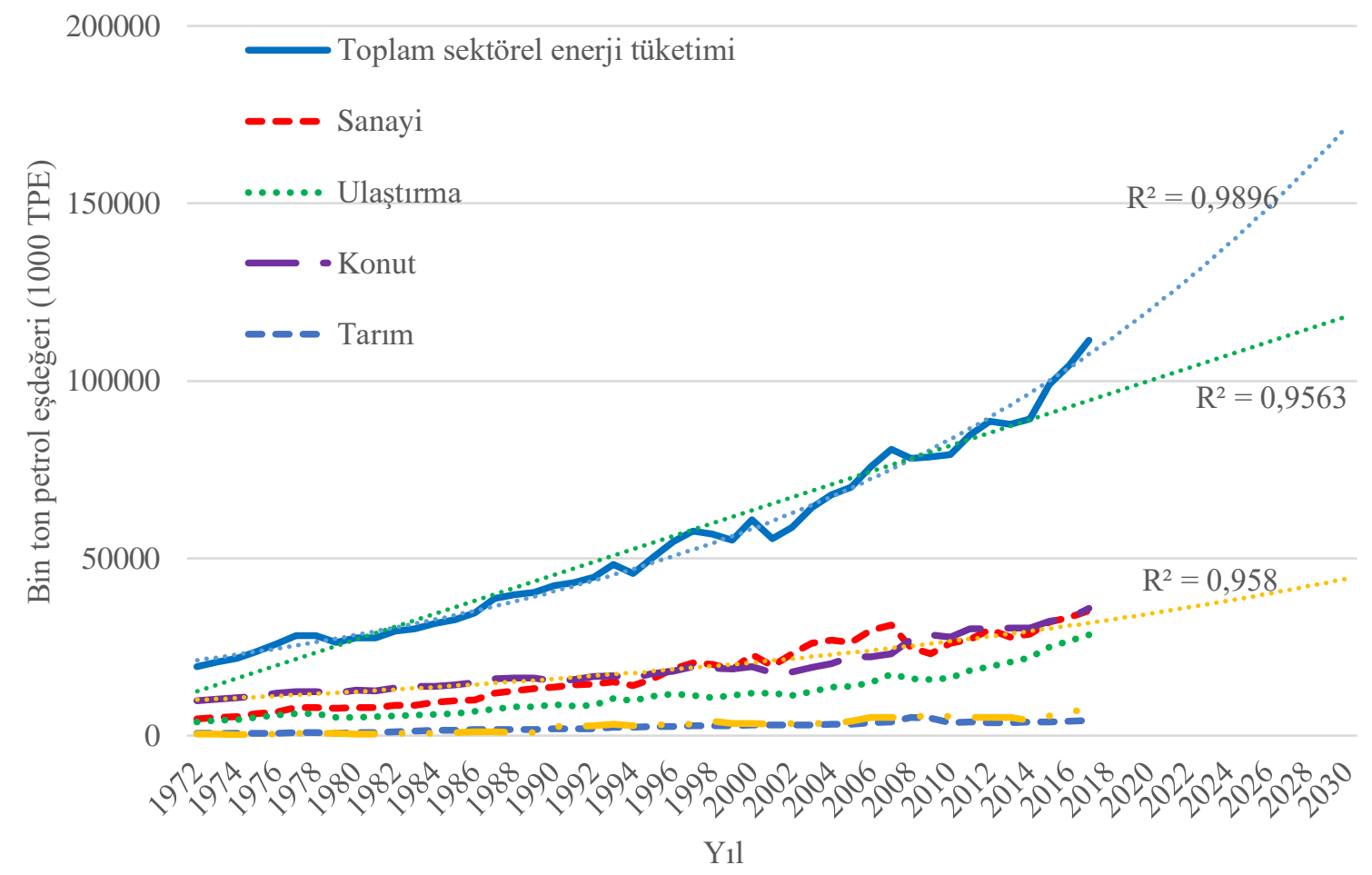

Şekil 1. Türkiye'de 1972-2017 yılları arasında toplam ve sektörel enerji tüketimi [3], ve 2030 yılı enerji tüketim tahminleri

Toplam ve konutların enerji tüketim seviyesinin tahmini olarak belirlenmesini kapsamında istatistiksel yöntemler kullanılarak 2030 y1lına kadar tüketim tahminleri belirlenmiştir. Toplam enerji tüketimi değerlendirildiğinde eğilim çizgilerinin belirttiği değerler arasında ciddi farklar olduğu gözlenmiştir. Toplam enerji tüketimi için doğrusal eğilim çizgisi 2030 yılı için yaklaşık 120 milyon TPE öngörmektedir. Üstel eğilim çizgisi ise aynı süre için yaklaşık 170 milyon TPE öngörmektedir. Her ne kadar iki eğilim çizgisinin $\mathrm{R}^{2}$ değerleri birbirine yakın olsa da iki modelin öngördüğü değerler arasındaki fark oldukça fazladır.

İstatistiksel değerlendirme yazılımı "Crystal Ball" kullanılarak daha ileri istatistiksel değerlendirmeler gerçekleştirilmiştir. Autoregressive integrated moving average (ARIMA) modeli kullanılarak yürütülen tahmin değerlendirmesi sonucunda 2030 yılında beklenen tüketim seviyesiyle beraber $\% 95$ güven aralığı da tespit edilmiştir. Bu kapsamda toplam tüketim ve yapılardaki tüketim ayrı ele alınmış ve Şekil 2 ve 3 'te sunulmuştur. 


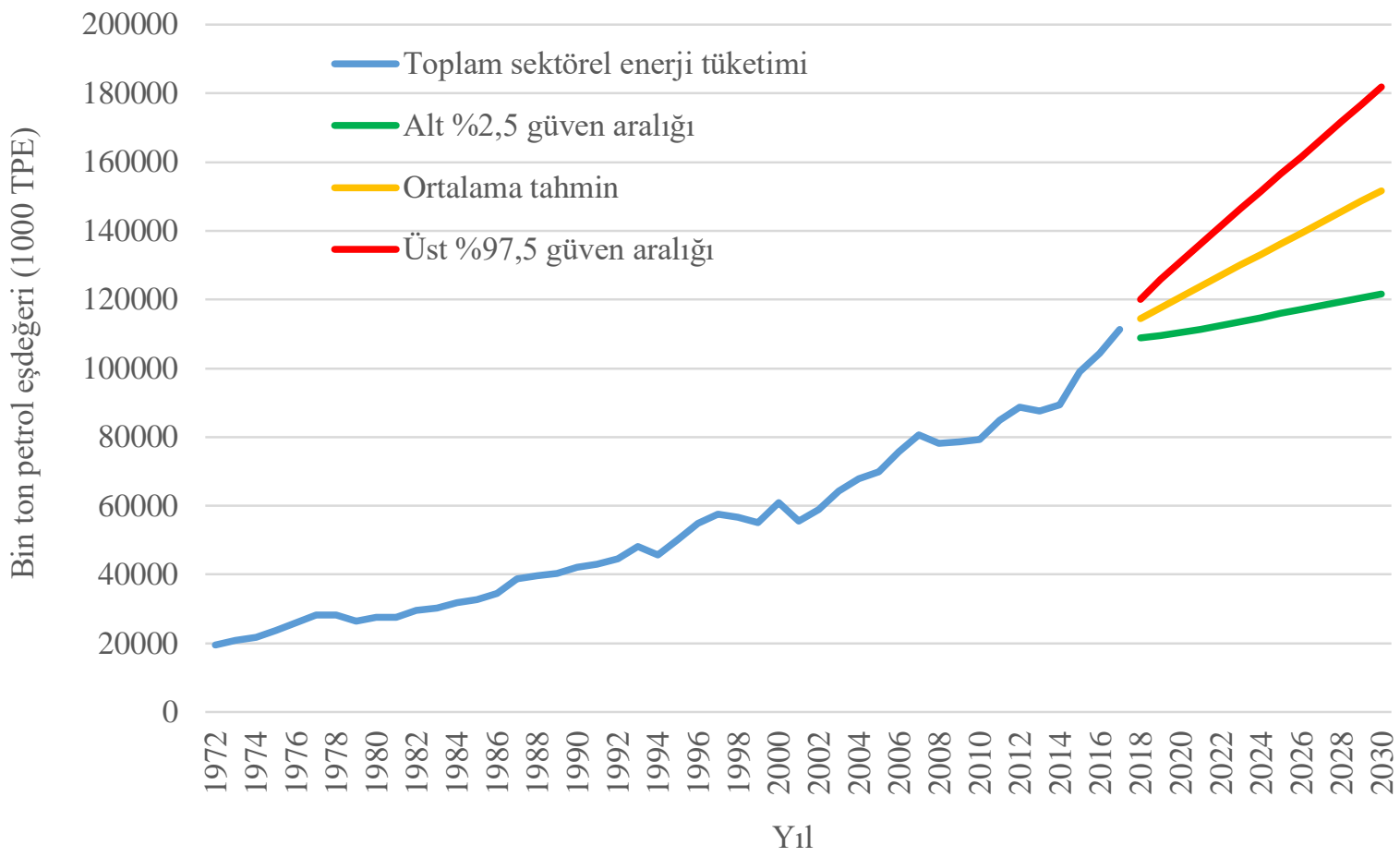

Şekil 2. 2030 yılında öngörülen toplam enerji tüketiminin ortalama tahmini değeri ve \%95 güven aralığı

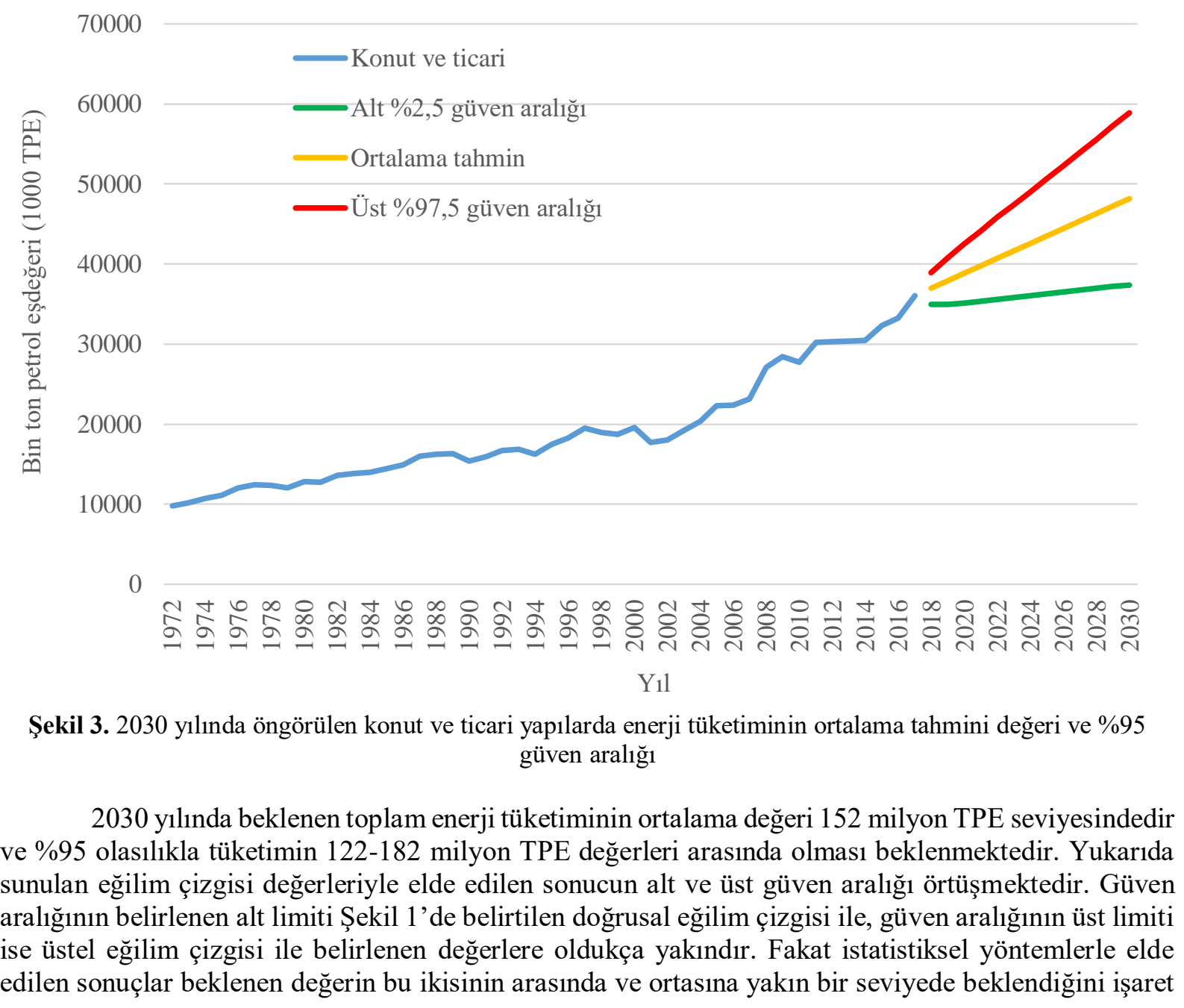


etmektedir. Ortalama değer göz önüne alındığında 2017 seviyesine kıyasla yaklaşık \%40 artış beklenmektedir. Güven aralığı ele alındığında \%95 olasılıkla 2030 yılına kadar \%10-65 kadar artış beklenmektedir.

Konut ve ticari yapılar için öngörülen enerji tüketim seviyesinin ortalama değeri 48 milyon TPE seviyesindedir. İlgili tahminin \%95 güven aralığı 37-59 milyon TPE seviyelerindedir. Bu değerler, 2017 yılı tüketimi olan 36 milyon TPE seviyesinden ortalama beklenti olarak \%33 artacağını, en iyi ihtimalle yatay seyredeceğini ve hızlı artış durumunda ise \%64 kadar artacağını göstermektedir.

\section{4. İthalatın toplam enerji arzındaki payı}

Mevcut veriler gösteriyor ki, Türkiye'deki birincil enerji arzını yerli kaynaklarla sağlamak en az son 50 yıldır mümkün olmamıştır. Bu süre zarfinda toplam enerji ihtiyacı tutarlı bir şekilde artmıştır. İthalatın oranı da aynı şekilde doğrusal bir eğilimle $\% 40$ seviyesinden $\% 85$ seviyesine çıkmıştır. Bu eğilimde üst limit \%100'dür ve bu değer Türkiye'nin tükettiği enerjinin hiçbir miktarını kendisinin üretmediğini simgeler. Enerji ithalatının toplama oranı Şekil 4 'te sunulmuştur. Eğilim en iyi $R^{2}$ değeri 0,97 olarak doğrusal eğilim çizgisiyle uyuşmaktadır.

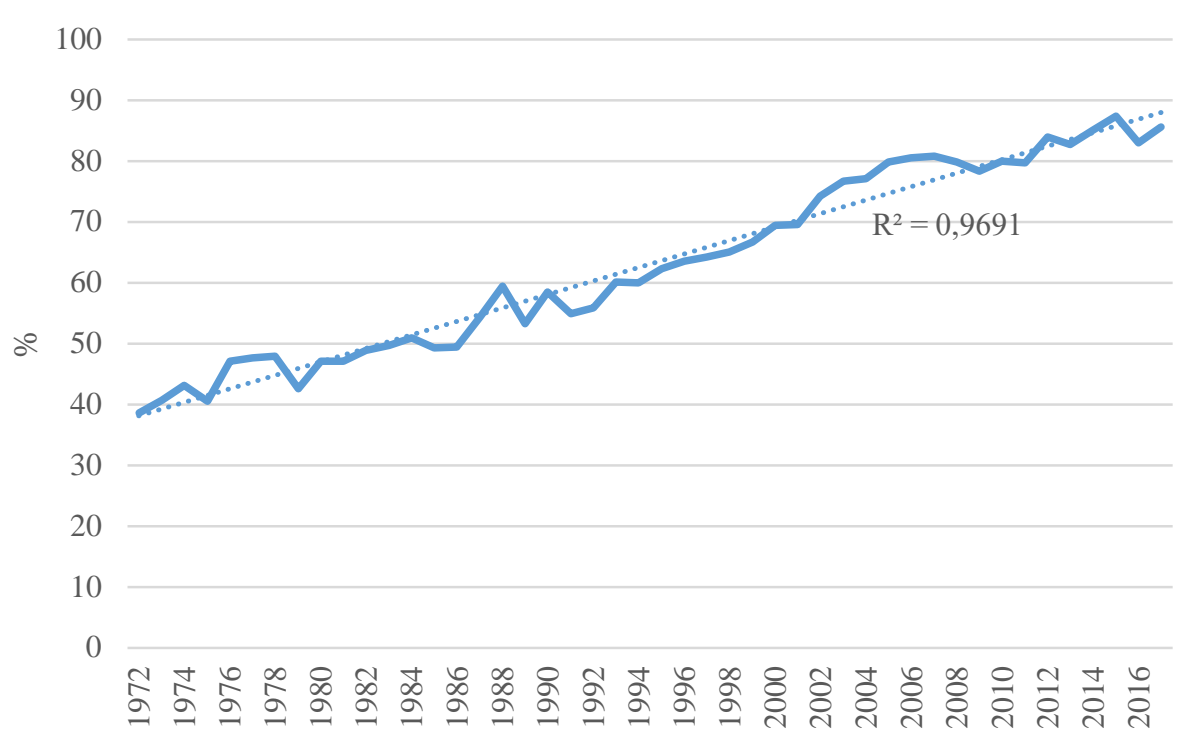

Şekil 4. 1972-2017 yılları arası ithalatın toplam enerji arzındaki oranı

\section{Kişi başına düşen enerji tüketimi}

Kişi başına düşen enerji tüketimi hem geleceğe yönelik tahminler yapmakta, hem de ülkeler arasında kıyaslama yapabilmek açısından önemlidir. Bu sebeple, Şekil 5 'te sunulan kişi başına düşen enerji tüketimi sunulmuştur. 2000 y1lı öncesi güvenilir kaynaklardan y1llık nüfus bilgisi temin edilemediğinden değerlendirme 2000-2017 yılları arasıyla sınırlandırılmıştır. Bu tarihten önce 5 veya 10 yıllık nüfus bilgisi mevcuttur fakat yürütülen istatistiksel değerlendirme açısından bu verilerin kullanımı sorunludur. Her ne kadar bu verilerin dahil edilmesi eğilim çizgisinde dikkate değer değişiklikler yaratmamışsa da tutarlılık adına bu veriler çalışmaya dahil edilmemiştir.

Sonuçlar Türkiye nüfusunu artmasına ek olarak, kişi başı enerji toplam enerji tüketiminin de tutarlı olarak arttığını ve 2000-2017 yılları arasında kişi başına enerji tüketiminin \%40 kadar arttığını göstermektedir. Belirlenen eğilim çizgisi yakın vadede ciddi değişikliklerin beklenmemesi gerektiğini işaret etmektedir. 


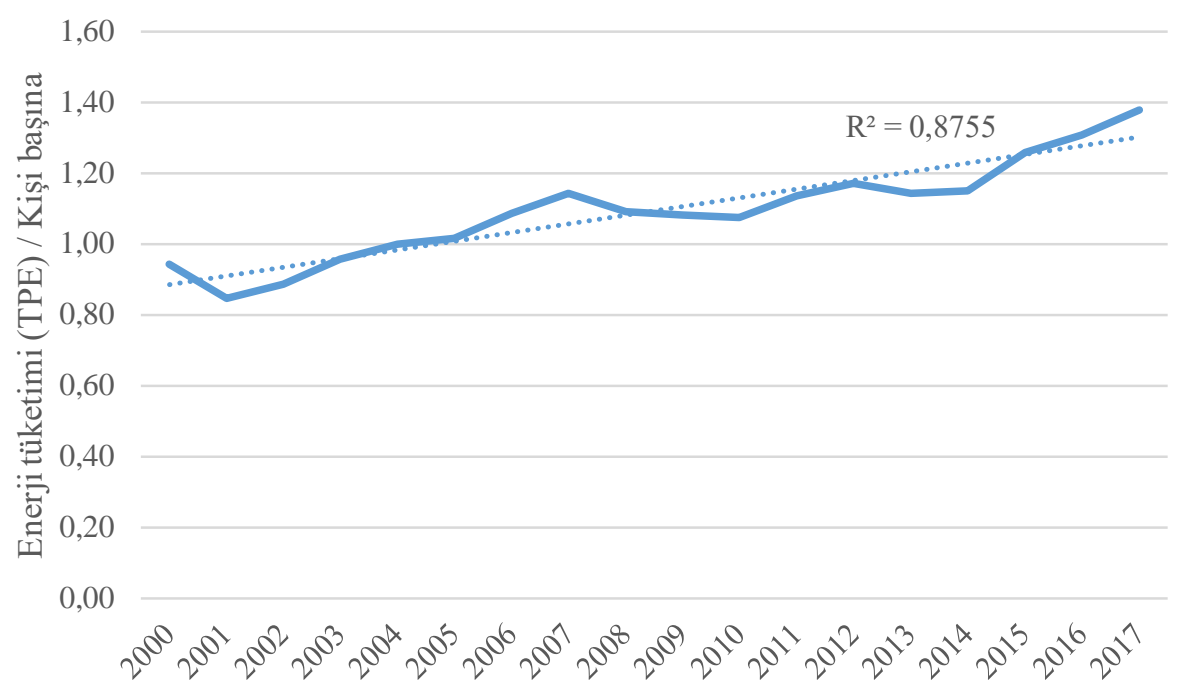

Şekil 5. 2000-2017 arası kişi başına düşen enerji tüketimi TPE cinsinden belirtilmiştir [4-6].

\section{Toplam ve yapılardaki enerji tüketimine en çok etki eden etkenler}

Ülkelerin enerji tüketimi nedensellik çalışmalarında en sık araştırılmış etken gayri safi yurtiçi hasıla (GSYH) olmuştur. Literatürde bu konu üzerine detaylı çalışmalar yürütüldüğü tespit edilmiştir $[7,8]$. Fakat bu çalışma esnasında sadece GSYH değil, enerji tüketimindeki artış eğrisini açıklayabilecek olası diğer etkenler de araştırılmıştır. Bunlar arasında, GSYH'ye ek olarak toplam ile konut ve ticari yapıların enerji tüketimi arasındaki ilişki ve nüfus, döviz kur endeksi ve petrol fiyat endeksi gibi etkenlerin korelasyonu da değerlendirilmiştir.

Yukarıda belirtilen etkenlerin enerji tüketimiyle olan korelasyonu Pearson korelasyon katsayıs1 kullanılarak değerlendirilmiş ve sonuçlar Tablo 1'de sunulmuştur. Pearson korelasyon katsayısı iki değişken arasındaki doğrusal korelasyonu belirlemede sıklıkla kullanılan istatistiksel bir yöntemdir. Sonuçlar -1 ve 1 aralığındadır. Değerler arttıkça değişkenler arasındaki korelasyonda kuvvetleniyor demektir. Sonuçların artı veya eksi olması doğrusal veya ters korelasyona işaret etmektedir. Sıfır değeri ise herhangi bir korelasyonun tespit edilemediğini belirtir.

Tablo 1. Toplam sektörel ve yapıların enerji tüketiminin belirlenen etkenlerle olan korelasyon değerleri. Sunulan değerler Pearson korelasyon katsayılarıdır. Değerlendirme için veriler sadece ulusal ve uluslararası resmi kaynaklardan temin edilmiștir [9-12].

\begin{tabular}{ccc}
\hline & $\begin{array}{c}\text { Toplam sektörel } \\
\text { enerji tüketimi }\end{array}$ & $\begin{array}{c}\text { Konut ve ticari yapilardaki } \\
\text { enerji tüketimi }\end{array}$ \\
\hline GSYH endeks (1972=100) & 0.989 & 0.985 \\
$\begin{array}{c}\text { Konut ve ticari yapılardaki } \\
\text { enerji tüketimi }\end{array}$ & 0.979 & - \\
Nüfus & 0.968 & 0.976 \\
Döviz kur endeksi & 0.924 & 0.912 \\
Petrol fiyat endeksi & 0.747 & 0.780 \\
\hline
\end{tabular}

Değerlendirilen etkenler arasından GSYH endeksinin etkisinin en fazla olduğu tespit edilmiştir, dolayısıyla Şekil 6'da endeksin çalışma süresince ne şekilde arttığı gösterilmiştir. Ü̉stel eğilim çizgisi $\mathrm{R}^{2}=0,99$ değeriyle en uygun eğilim olarak belirlenmiştir. 


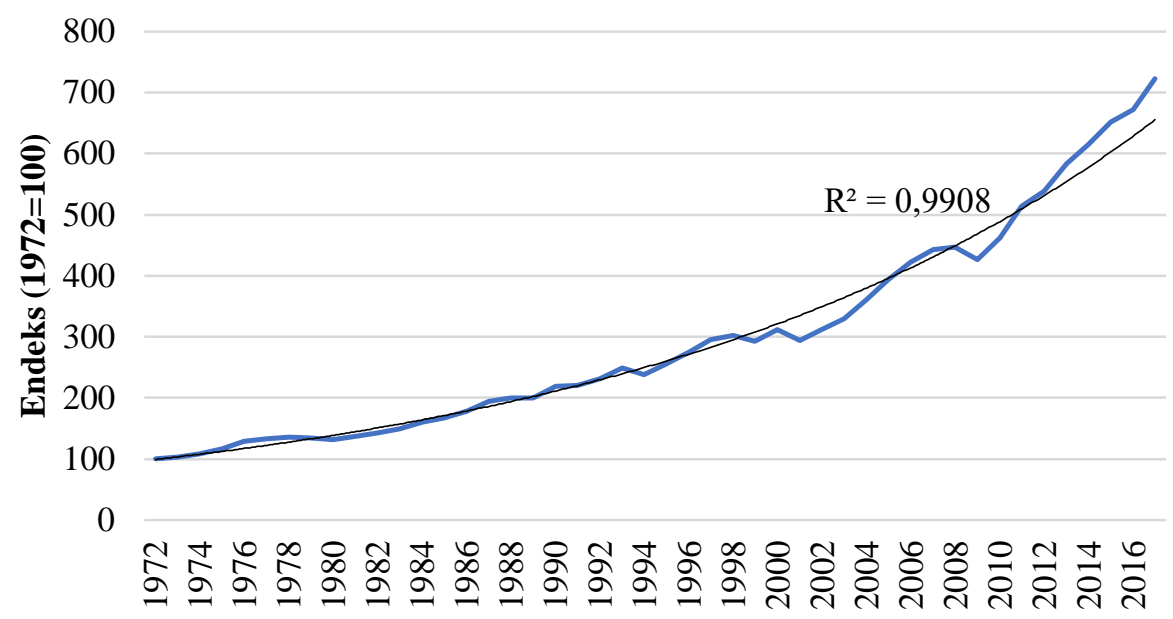

Şekil 6. Gayri safi yurtiçi hasıla endeksinin 1972-2017 yılları arası değişimi. Endeks değeri 1972 yılında 100 olarak kabul edilmiş ve takip eden yıllardaki endeks değeri buna göreceli olarak belirlenmiştir.

\section{Yapı enerji verimliliği hedeflerinin belirlenmesi}

Ulusal enerji tüketiminin kontrol altına alınabilmesi için konutlarda gerekli enerji verimliliği hedeflerinin belirlenmesinde yukarıda belirtilen istatistiksel değerler temel alınmıştır. Bu kapsamda hedeflenen, etkin politika ve tekniklerle enerji tüketim seviyesinin mümkün olduğunca aşağı çekilmesidir. Mevcut veriler ve değerlendirmeler Türkiye'nin toplam enerji seviyesini 2017 y1lı seviyesinde korumasının sadece yapıların enerji verimliliği ile mümkün olmadığını göstermektedir. Zira toplam enerji tüketimindeki ortalama beklenti, 2017 yılı tüketim seviyesinden 41 milyon TPE daha yüksektir, ki bu rakam aynı yıl için konut, ticari ve hizmet binalarının tükettiği enerji seviyesinden daha yüksektir. Dolayısıyla, toplam enerji tüketiminin kısa vadede sabitlenmesi veya azalması olas1 gözükmemektedir. Artan nüfus ve kişi başına düşen enerji tüketimi değerleri de bu sonucu desteklemektedir. Yapılması gereken çevresel, sosyal ve ekonomik hedef ve önceliklerin belirlenmesi ve enerji tüketiminin artacağı varsayımıyla bu hedeflere doğru etkin politikalar geliştirilmesi ve uygulanmasidır.

\section{Sonuçlar}

Mevcut çalışma, Türkiye'deki enerji tüketiminin istatistiksel tahmini, binaların genel toplamdaki payı ve mevcut tüketim seviyesinin korunması veya azaltılması için yapılarda enerji verimliliği hedeflerinin tespit edilmesini kapsamaktadır. Çalışma yürürlükte olan devlet politikalarını bilimsel olarak desteklemekte ve sonuçlarıyla katkıda bulunmaktadır. Çalışma aynı zamanda sonuçları itibariyle Türkiye'nin enerji altyapısındaki sistematik esnekliği artırmaya ve mevcut enerji bağımlılık ve güvenlik açıklıklarının belirlenmesi ve nihai olarak azaltılmasını hedeflemektedir. Enerji tüketim seviyesinin istatistiksel değerlendirmesi sonucu elde edilen güven aralığı ulusal enerji politikalarına ve önceliklerine yön verme potansiyeli açısından da son derece önemlidir.

2030 y1lında beklenen toplam enerji tüketiminin ortalama değeri 152 milyon TPE seviyesindedir ve \%95 olasılıkla tüketimin 122-182 milyon TPE değerleri arasında olması beklenmektedir. Ortalama değer göz önüne alındığında 2017 seviyesine kıyasla 14 yıl içinde yaklaşık \%40 artış beklenmektedir. Güven aralığı ele alındığında ise \%95 olasılıkla 2030 yılına kadar \%10-65 kadar artış beklenmektedir. Sonuçlar, Türkiye nüfusunun artmasına ek olarak, kişi başı toplam enerji tüketiminin de tutarlı olarak arttığını ve 2000-2017 yılları arasında kişi başına enerji tüketiminin \%40 kadar arttığını göstermektedir.

Konut ve ticari yapılar için öngörülen enerji tüketim seviyesinin ortalama değeri 48 milyon TPE seviyesindedir. İlgili tahminin \%95 güven aralığı 37-59 milyon TPE seviyelerindedir. Bu değerler, 2017 yılı tüketimi olan 36 milyon TPE seviyesinden ortalama beklenti olarak \%33 artacağını, en iyi ihtimalle yatay seyredeceğini ve hızlı artış durumunda ise \%64 kadar artacağını göstermektedir. 
Mevcut veriler gösteriyor ki, Türkiye'deki birincil enerji arzını yerli kaynaklarla sağlamak en az son 50 yıldır mümkün olmamıştır. Bu süre zarfında toplam enerji ihtiyacı tutarlı bir şekilde artmıştır. İthalatın toplama oranı da aynı şekilde doğrusal bir eğilimle $\% 40$ seviyesinden $\% 85$ seviyesine çıkmıştır.

Enerji tüketimini etkileyen etkenler incelendiğinde, GSYH'ye ek olarak toplam ile konut ve ticari yapıların enerji tüketimi arasındaki ilişki, nüfus, döviz kur endeksi ve petrol fiyat endeksi gibi etkenlerin korelasyonu da değerlendirilmiştir. Değerlendirilen etkenler arasından GSYH endeksinin enerji tüketimine etkisinin en fazla olduğu tespit edilmiştir.

Mevcut veriler ve değerlendirmeler Türkiye'nin toplam enerji seviyesini 2017 y1lı seviyesinde korumasının sadece yapıların enerji verimliliği ile mümkün olmadığını göstermektedir. Buna ek olarak, toplam enerji tüketiminin kısa vadede sabitlenmesi veya azalması olası gözükmemektedir. Artan nüfus ve kişi başına düşen enerji tüketimi değerleri de bu sonucu desteklemektedir. Yapılması gereken çevresel, sosyal ve ekonomik hedef ve önceliklerin belirlenmesi ve enerji tüketiminin artacağı varsayımıyla bu hedeflere doğru etkin politikalar geliştirilmesi ve uygulanmasıdır.

\section{Teşekkür}

Bu çalışma TÜBİTAK tarafindan 2232 Yurda Dönüş Araştırma Burs Programı kapsamında desteklenmiştir. Bu yazıda dile getirilen herhangi bir görüş, bulgu ve sonuç ya da tavsiye yazarlara aittir ve TÜBİTAK'ın görüşlerini yansıtmayabilir.

\section{Kaynaklar}

[1] UNDP, 2010. Promoting Energy Efficiency in Buildings, United Nations Development Programme, July 2010.

[2] MFA, 2017. Turkey's Energy Profile and Strategy, Ministry of Foreign Affairs. http://www.mfa.gov.tr/turkeys-energy-strategy.en.mfa (Erişim Tarihi: 01.06.2017).

[3] Enerji İşleri Genel Müdürlügüü. İstatistikler - Denge Tabloları, T.C. Enerji ve Tabii Kaynaklar Bakanlığ1, http://www.eigm.gov.tr/tr-TR/Denge-Tablolari/Denge-Tablolari?page=1 (Erişim Tarihi: 01.07.2018).

[4] TÜİK. Temel İstatistikler, Nüfus ve Demografi-Nüfus Projeksiyonları-Y1llara Göre Nüfus, 20182080. 2019. Türkiye İstatistik Kurumu, http://www.tuik.gov.tr/UstMenu.do?metod=temelist (Erişim Tarihi: 15.02.2019).

[5] TÜİK. Temel İstatistikler, Nüfus ve Demografi-Nüfus İstatistikleri-Yıllara Göre İl Nüfusları 2000-2018. 2019. Türkiye İstatistik Kurumu, http://www.tuik.gov.tr/UstMenu.do?metod=temelist (Erişim Tarihi: 15.02.2019).

[6] TÜiK. Veritabanları-Genel Nüfus Sayımları. 2019. Türkiye İstatistik Kurumu, http://www.tuik.gov.tr/VeriTabanlari.do?vt_id=27\&ust_id=109 (Erişim Tarihi: 15.02.2019).

[7] Korkmaz Ö., Develi A. 2012. Türkiye'de Birincil Enerji Kullanımı, Üretimi ve Gayri Safi Yurt İçi Hasıla (GSYİH) Arasındaki İlişki, Dokuz Eylül Üniversitesi İktisadi ve İdari Bilimler Fakültesi Dergisi, 27(2): 1-25.

[8] Lise W., Van Montfort K. 2005. Energy Consumption and GDP in Turkey: Is there a CoIntegration Relationship?, EcoMod 2005 Interantional Conference on Policy Modeling, Haziran 2005, İstanbul, Türkiye.

[9] TÜİK. Temel İstatistikler, Ulusal Hesaplar - Harcama Yöntemi ile GSYH - Gayrisafi yurtiçi hasıla, harcama yöntemiyle zincirlenmiş hacim, endeks ve değişim oranları, 1998-2017. Türkiye İstatistik Kurumu, http://www.tuik.gov.tr/UstMenu.do?metod=temelist (Erişim Tarihi: 15.02.2019).

[10] World Bank Open Data. GDP (constant 2010 US\$). World Bank, 2019. https://data. worldbank.org/indicator/NY.GDP.MKTP.KD?end=2017\&locations=TR\&start=197 2\&view=chart (Erişim Tarihi: 15.02.2019).

[11] TCMB. Elektronik Veri Dağıtım Sistemi. Kurlar-Döviz kurları. Türkiye Cumhuriyeti Merkez Bankas1. https://evds2.tcmb.gov.tr/index.php?/evds/serieMarket/\#collapse_2 (Erişim Tarihi: 15.02.2019).

[12] EIA. Petroleum \& Other Liquids-Data, U.S. Energy Information Administration, 2019. https://www.eia.gov/dnav/pet/hist/RWTCD.htm (Erişim Tarihi: 15.02.2019). 
C.B Aktaş / BEÜ Fen Bilimleri Dergisi 8 (4), 1422-1431, 2019 